\title{
The Social Construction of Public Infrastructure: The Case of the Dutch National Geo-information Clearinghouse Project
}

\author{
Henk Koerten \\ Delft University of Technology \\ Marcel Veenswijk \\ Vrije Universiteit Amsterdam
}

\begin{abstract}
Disclosure of governmental map related information is increasingly being conceptualized as management of inter-organizational National Spatial Data Infrastructures (NSDIs). Until now, studies have been published on how NSDI projects should be designed, set up and monitored. While these approaches have gained some recognition when applied in practice, little is known about what happens when design rules are translated into daily project routines. Social scientific research into how NSDIs are defined, and how they develop and mature is scarce. This paper focuses on how infrastructure is conceptualized in NSDI projects. We present and analyze ethnography of the development of the Dutch National Geo-information Clearinghouse (NCGI). A narrative approach is used to find out how the NCGI was conceptualized, how it emerged, developed, and changed, and how it was appraised. The research finds that actors held storyboards consisting of predefined scripts, which guided their behavior and defined the project outcomes.
\end{abstract}

\section{INTRODUCTION}

The growing importance of map-related information in society has caused a tremendous increase in inter-organizational geo-data exchange over the last ten years, particularly in not-forprofit and governmental settings. This increase has both been stimulated and contained by the use of metadata to structure and standardize information (Masser, 2005). At the national level, geo-data exchange has been stimulated worldwide by the development of clearinghouses (Crompvoets, 2006). Initially intended as focal points for inter-organizational geo-data exchange, these are now seen as constituting an important step towards the emergence of overarching geodata exchange systems, otherwise known as National Spatial Data Infrastructures (NSDIs) (Rajabifard and Williamson, 2001).

Until now, policy advisors have been aware of the organizational aspects of clearinghouse development. However, these have rarely been treated as manageable phenomena (Georgiadou, Puri, and Sahay, 2005; Crompvoets, Rajabifard, Van Loenen, and Delgado Fernández, 2008), as 
it has been assumed that the technical aspects of clearinghouses are more important (Nebert, 2004). As a result, the organizational aspects have been overlooked, and with them, the relationship between organizational change and NSDI implementation (Koerten, 2008). The research to date has thus not focused on clearinghouses' organizational- and project structures, modes of cooperation and work relations (Georgiadou, 2006).

Slowly but surely, organizational aspects are now increasingly being taken into account in NSDI research (Van den Toorn and De Man, 2000). Studies have shown a propensity to apply designs rules borrowed from political science, economics and management science to the organizational aspects of NSDI, however, and have thereby ignored implementation processes (Koerten, 2008). While practitioners have identified difficulties with implementation, this essentially remains an uncontested field of research.

In this ethnography of the development of a clearinghouse, we focus on NSDI development in everyday practice. The research is based on a narrative approach to the development of the clearinghouse concept. The approach offers a means of tackling the debates, disputes and discrepancies within the community that conceived and oversaw both the development and the eventual disbanding of the clearinghouse in question.

This article presents the case of the Dutch clearinghouse NCGI (Nationaal Clearinghouse Geo-Informatie). We focus on the processes that shaped the emergence, development and fate of this NSDI. The participants' experiences offer clues as to how technologically challenging projects were conceptualized, motivated, executed and evaluated. Our research question is thus: how can NSDI implementation projects be explained using narrative analysis? Using a narrative approach allows us to track the project's course, analyzing the concepts and images held by the participants at the start of the project, and during its development and eventual disbanding.

A clearinghouse is generally understood to be a central access point where geo-information is collated and disseminated among users. In the early days of the NCGI, technical limitations meant that a much narrower notion of a clearinghouse was employed; at the beginning, it was only seen as a catalogue for geo-metadata. As the exchange of geo-data started to become almost entirely electronic, the decision was made to set up an electronic exchange function, preferably one that was Internet-based.

The concept of a clearinghouse was first developed in the United States, where it entered the agenda in the early 1990s as a means of disclosing governmental information on environmental policy formulation. In the Netherlands, the notion of a clearinghouse was introduced by RAVI (Overlegorgaan Raad voor de Vastgoedinformatie), a Dutch government-funded network organization on geo-information standardization and policy development. In the context of the NCGI, RAVI was viewed as an institute that would be able to transform a limited, rudimentary metadata-cataloguing initiative into an institutionalized national branch exchange for geo-data. Having conducted some initial exploratory activities, the NCGI was officially launched in 1997 as an independent organization, with a supervisory board composed of management executives from nationally-operating geo-data-handling organizations.

From its creation to its eventual disbanding, the NCGI was a web-based initiative. As a result, the project underwent some significant redefinitions, which were loosely coupled to the general process of Internet service maturation. Nevertheless, the genesis and fate of the NCGI unquestionably had their own internal dynamics, which will be revealed in this paper.

The outline structure of the paper is as follows. In section two, we explain our theoretical approach. Section three offers an account of the research method. Section four sets out the case in detail, and an analysis and conclusion are presented in section five. 


\section{THE NARRATIVE APPROACH TO RESEARCH}

Goffman expanded the theory of symbolic interactionism by using the theatrical terms, 'front stage' and 'back stage', thereby stressing our ability, as humans, to see ourselves from other points of view (Goffman, 1959). Goffman did not specify how these ritualistic frames might emerge, however (Goffman, 1974; Gonos, 1977). Bourdieu implied that such structures are socially constructed and using concepts such as 'habitus', 'practice', 'doxa' and 'field', he conceptualized a network of relations among objective positions external to individuals (Bourdieu, 1977; Bourdieu and Pels, 1989). These positions had economic, cultural, social and symbolic capital, while field and habitus defined one another in a dialectical relationship (Bourdieu, 1998).

Goffman's notion of 'frames' resembles Bourdieu's concept of field. Moreover, Bourdieu's notion of practice is more or less interchangeable with Goffman's concept of the 'front stage'. However, both theorists failed to address the issue of how meaning is created. Their implicit assumptions of univocality, ubiquitousness and fully-informed actors overlooked the possibility of ambivalent, ambiguous and incomplete worldviews.

We intend to go beyond notions of front stage and practice and focus on extending the interpretation of lived experience as a guide for action to a narrative approach, using interpretation, meaning creation and sense-making as the guiding concepts of a less positivistic method (Polkinghorne, 1988; Hatch and Yanow, 2003). In doing so, we identify two approaches: a discourse-oriented 'linguistic turn', and a story-oriented 'narrative turn' (Verduijn, 2007).

Discourse makes linguistic sense of people's writing, reading, speaking and discussing actions, as the use of messages to convey myths, sagas, results, setbacks, challenges or strategies (Ricoeur, 1973; Grant, Hardy, Oswick, and Putnam, 2004). The dynamics of organizational practice have invoked interest in metaphor, stories and drama (Grant, Keenoy, and Oswick, 1998). Grounded in literary criticism, new methods of analysis have emerged as part of the socalled 'narrative turn', which aims to delineate stories and storylines rather than texts (Burke, 1969; Gabriel, 2000). The concept of narrative can be regarded as the structuring of human memory. As such, it is both a medium and a process (Bruner, 1991), helping to make the notion of organization more dynamic (Hatch and Yanow, 2003).

We use narratives to give meaning to experience, by interpreting stories in a desired manner (Gabriel, 2000). Whether they are told once or endlessly retold, stories are altered and become a frame of reference for future stories and actions. As such, they become narratives that are loosely or even poorly connected to the original (Boje, 2001; Tesselaar, Sabelis, and Ligtvoet, 2008). They become universal images, culminating in identity creation (Beech and Huxham, 2003). From managers to company cars, identities are created in a process of storytelling that leads to the continuous reconstruction of narratives, whether these are prominent or latent, conscious or unconscious, real or imagined (Boje, 2001). In search of a clear overall picture, the blanks are filled with fantasies that function as experiences (Ricoeur, 1973; Bruner, 1991).

Humans only notice change when it is reduced to a series of instances (Bergson, 1946; Burrell, 1992). An influx of stimuli is converted into adequate fixed concepts for sense-making (Chia, 2002). While shifts in meaning rarely occur, however, changes do gradually take place. Stable narratives in changing circumstances have the quality of a 'deep structure' (Douglas, 1986; Schein, 1992). Our framework conceptualizes the creation and maintenance of stable narratives 
about scenes, actors and actions, in terms of their narrative settings, narrative spaces and narrative storyboards respectively (see figure 1).

The narrative setting conceptualizes narratives about the environment and time. A location is enacted using images from the past, present and future, from the local community to the global environment (Douglas, 1986; Lefebvre, 1991). As they entail the physical environment (Yanow, 1995) and technology (Orlikowski, 2000), locations may have different meanings that relate to tangible and non-tangible aspects (Lefebvre, 1991; Weick, 1995). An intangible software program that runs on a tangible computer, for instance, may have a fundamental impact on how things are done (Orlikowski, 2000). Technology is shaped by subjective, partial and distorted images of application (Bijker, 1995; Orlikowski, 2007) that are linked to time and space (Burrell, 1992). This creates a relatively stable image of the environment, which is only redefined when it becomes untenable.

FIGURE 1

THEORETICAL FOCUS

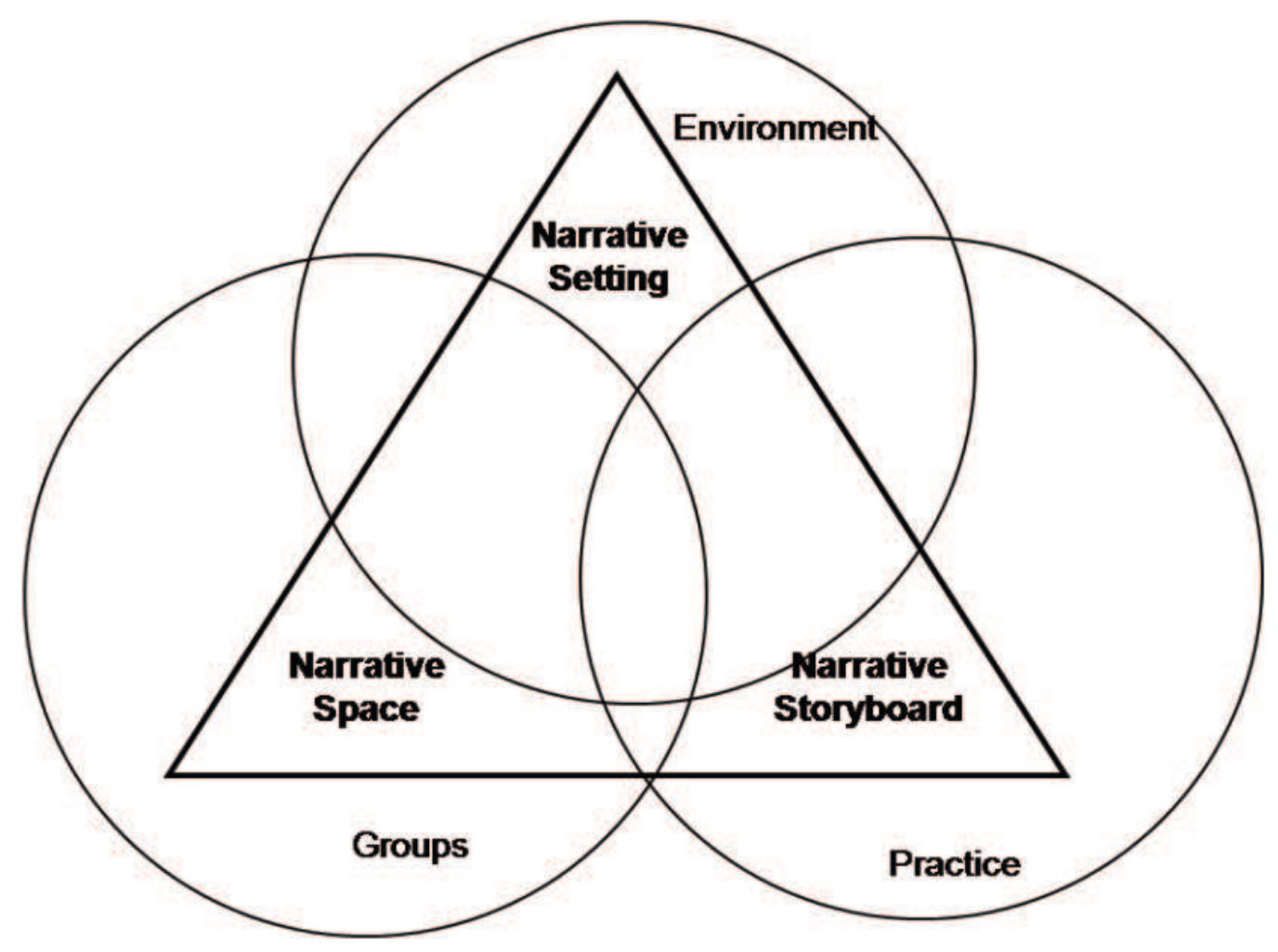

Narrative spaces refer to departments, organizations, professions, religions or any other enacted configuration of actors (Weick, 1995). Functioning implicitly and explicitly as mental 'zoning plans' for enacted human groups, their dynamics invoke action or conversely create deadlocks or ceasefires. They may form quite complex combinations that are not necessarily 
linked to formal organizational structures (Lipsky, 1980; Schein, 1996). Again, change is conceptualized as the move from one form of stability to another (Barley, 1990; Bartunek, 2004).

Narrative storyboards are the bedrock of human action. They provide predefined scripts in a world that is made up of a constant flow of events, and create fixed recipes for action that are based on past, present and future actions (Bergson, 1946; Berger and Luckmann, 1967; Bourdieu, 1977; Weick, 1995). As people feel uncomfortable when the mostly unwritten rules are not appropriately applied (Garfinkel, 1984), storyboards provide a narrative for moving from one state of affairs to the other, linking the action in question to time and space. They can guide apprentices learning the general way of doing things (Wenger, 1998), can help moving from chaos to order (Latour and Woolgar, 1986), and make people to know what to expect (Czarniawska-Joerges, 1998). Their predictable features make them triggers for change. They provide building blocks for analyzing change, and shed light on how narrative change can be mapped (Boje, 1995).

\section{METHOD}

This paper presents an ethnography of the NCGI, which ran from 1997 until the end of 2006. We offer an account of the events prior to the NCGI's creation, and analyze its development and disbanding. In doing so, we demonstrate that narratives change during the course of events.

The research commenced after the NCGI had been disbanded in 2006. I tried to engage in the geoinformation community as much as possible by visiting congresses, seminars and workshops, where it was relatively easy to approach relevant key players in NCGI, introducing myself as a researcher interested in the organizational aspects of geoinformation infrastructures. Such an introduction often prompted people to offer their opinions on NCGI and spatial data infrastructures in general. Afterwards, I always made notes of these spontaneous encounters as they provided me with 'soft' information, sometimes even with clear stories of personal experiences.

These encounters have lead to 18 appointed interviews with individuals at their work locations. At first, the persons approached were mostly key persons, willing to grant me an interview and being helpful to give further names and to get to grips with crucial jargon. They also pointed at less obvious aspects of NCGI, such as the preliminary SAG-initiative. By following the snowball method, I managed to interview a variety of people, of which some had been closely involved with the NCGI, while others had played a more distant role.

When I approached potential interviewees I always stated my intentions and purpose. Presenting myself as an outsider, my counterparts were almost automatically forced into the expert role, prompting to demonstrate their knowledge of the subject, rendering rich and abundant information. I invited them to tell the story of their working life, preferably starting with their education, after which I asked them specific questions on certain topics that needed further elucidation. A full interview report was written as soon as possible after the completion of the interview. These interviews were held in 2006 and 2007.

Relevant documents and websites also have been used as sources of stories and opinions. During its existence NCGI has published bi-monthly newsletters in a leading Dutch professional journal for the geo-information sector, which provided me an 'official' account of the NCGI and RAVI. The SAG initiative, an essential element of the NCGI case, was documented in the proceedings of a few conferences on that topic. As NCGI had been extensively covered by professional journal articles, both these articles and interviews provided me with rich stories. 
An ethnography has to be authentic ('been there'), plausible (relevant for the reader) and analytically critical (Golden-Biddle and Locke, 1993). In order to do this, we followed the writing conventions developed by Watson and extended by Duijnhoven on transferring field notes into convincing, authentic texts (Duijnhoven, 2010; Watson, 2000). To meet the requirements developed by Golden-Biddle and Locke, in the account that follows, we present representations of conversations that are largely extracted from conversations recorded in interviews and, to a small extent, from field notes.

The research revealed the existence of a narrative setting that was dominated by the continuous development of (Internet) technology. The most relevant narrative spaces were those of the geo-professionals and the geo-management. Geo-management individuals seemed to be concerned with the interests of the organizations they represented, while the geo-professionals tended to promote the common cause of geo-information sharing. The NCGI was the arena in which narratives of change were created, contested, appropriated and diffused. Both the narrative scene and the narrative spaces seem to have caused the individuals involved to develop their own storyboards as prescriptions for action. How these storyboards developed will be shown in the next section.

\section{CASE DESCRIPTION}

In this section, we present a close description of the case aimed at narrative analysis. It covers the period between preliminary developments starting in 1984 up to the organization's disbanding in 2006.

\section{Preparations and Getting Started}

It appears that the concept of a clearinghouse was first developed by the Clinton administration (Clinton, 1994). In the US, a central Internet-based facility for advancing the disclosure of geo-information was used to host a catalogue of structured governmental geometadata. Datasets were described using metadata, allowing potential users to browse the clearinghouse catalogue to find out which data would suit their purpose. In 1995, RAVI, a Dutch government-funded independent policy-development and network institute, made efforts to establish a geo-data clearinghouse in the Netherlands.

At that time, a few interviewees had already become involved in the Samenwerkende Aardkundige Gegevensverstrekkende Instituten (Joint Geographical Data Organizations initiative, SAG), which aimed to further cooperation between research institutions on geographical data delivery. This cooperation had started as early as 1984, when four national governmental research institutes on geology, subsoil water, the countryside and the environment announced their intention to cooperate on geo-data delivery (Boswinkel, 1991; Hooghart, 1991). They promoted a system of standardization that would eventually lead to a national unified system for mutual data exchange, which could also deliver data to other governmental agencies. The initiative was relatively formal, and included deliberations in assemblies and conferences, discussions on modes of cooperation, and announcements of milestones (Boswinkel, 1991; Lentjes, Bregt, Jellema, Kuipers, and Thewessen, 1993).

While the SAG initiative was not seen as successful, it was thought to have stimulated informal cooperation between the individuals involved. As a geo-data professional explains: 
"The SAG initiative had created social support. We helped each other whenever we could and stayed in touch. Then the idea of a product catalogue was raised. Some kind of data bin had to be developed, which was later called a clearinghouse. This was separate from my own organization."

In the 1990s, the environment started to dominate public debates (Handelsblad, 1995), and this further stimulated geo-information use (RIVM, 1993). By this time, GIS and geoinformation had become 'hot topics', as a SAG staff member explained:

"We were 'GIS-alising' environmental policies. Thanks to GIS, we were able to put micro-scale data in a national perspective. Environmental policy was booming at that time, and that created a tremendous need for environmental data. As GIS-specialists, this gave us strength; we were able to set things in motion. Nationally and internationally, we had intensive contact with like-minded colleagues. We were putting a lot of effort into collecting geo-data from other organizations, and converting and harmonizing it to match ours. The fact that we used geo-data from other sources was part of our success."

The professional staff from former SAG-organizations developed a strong bond, acting as a relatively closed group in their efforts to develop software for collecting and disseminating geodata. One insider observed:

"The environment was hot. We were in the spotlight, and suddenly it all seemed to happen. In order to do what we were supposed to, we needed geo-data, and also a great deal from others. As a bunch of geo-specialists, we tried and tried, and eventually it resulted in a working prototype of a catalogue. But initially, it just looked like one big dream."

With a budget of 110,000 Euros, in 1995, this informal club developed the Idéfix system: a metadata catalogue that described some 250 geo-datasets, which was owned by participating organizations. These participants considered data-sharing to be something that could only be dreamed of, an idée fixe. One project member observed:

"Idéfix was a classic project. A few organizations were mutually dependent upon each other's data; they brought money in, and off it went. Somebody wrote a project plan and we built the prototype in six months. That first version of the clearinghouse, based on Idéfix, was the best; after that it declined. It was not maintained, and eventually became outdated."

This software application was later seen as the preliminary version of a large-scale application. When the application was up and running, it was handed over to RAVI with the intention that RAVI should advance and institutionalize it. The project's initiators thought that their idea was now in the hands of capable people, who would further advance it and give it national application. 


\section{Attempts to Mature}

Around 1995, the policy advisory organization RAVI introduced the clearinghouse concept to the Netherlands. As a former member of staff explains:

"At that particular US conference, the concept was brought to life. They presented the case of bush fires. It was asserted that all the data that were needed to assess whether or not these fires were harmful to the environment were already there, but they were not findable, let alone accessible. They were in different datasets with different organizations in different formats on different scales. To be able to connect these datasets, a clearinghouse was needed. Datasets should be registered in a clearinghouse, so anybody who was interested could easily decide which datasets to use."

Unlike the US initiative, the Dutch clearinghouse concept was not driven by environmental concerns. At RAVI, Idéfix was seen as a technical response to the need for a clearinghouse, which had only to be institutionalized in order to be successful in an operational sense. The geoprofessionals thought Idéfix had been a success, and wanted to see it applied in a broader context:

"In spite of considerable opposition, Idéfix was developed within six months. Now we had something that was likely to be successful, but lacked an institutional basis. That was the moment to call in RAVI. We just said: we geo-specialists have built this system: now it is up to RAVI to take it further. Institutionalize it and make it a success."

"The process of professionalization created distance between the initiators and the catalogue. I had the feeling that it wasn't ours anymore. The link between creativity and NCGI was gone, and idealism no longer had a chance. NCGI was made into a product in a business environment too quickly, when it wasn't ready for it."

The NCGI, which was based on Idéfix, was launched in October 1997 as a solution to the problem of locating geo-information. The process of institutionalization meant that it was established as an independent foundation that was aimed at the geo-sector as a whole. A former RAVI employee explains:

"To get going, we had to go out and sell our idea of a clearinghouse. Because it was supposed to be for the national geo-information sector as a whole, we went to business fairs and conferences to promote it. But organizations were reluctant to join. We received a lot of verbal support, but still nobody was actually joining."

"The NCGI was to have been the Yellow Pages for geo-information on the Internet. Looking for geo-information, you were supposed to browse through these pages. Having found what you were looking for, you could send an e-mail to the contact person of the data source to get your dataset delivered on CD-ROM. After some time, this was seen as an old-fashioned system; not only metadata, but also the geo-data itself should be disseminated through the Internet. We had just one goal: to make geo-information findable and accessible. NCGI was the means to that." 
The NCGI, which was now financially independent from RAVI, had management executives from constituting organizations on its supervisory board (Bregt, 2000). They felt that the NCGI was ready to play a professional role at the national level. A former supervisory board member explains:
"A general manager of the NCGI was appointed. He invited organizations to join by asking them to participate and to donate money. That was not a wise thing to do; at least, it did not help the NCGI at all. We were to have a professionally-hosted website, done by a professional and competent software company for a monthly fee. In an attempt to cut costs, the NCGI website was redesigned by a software company, which got us into technical difficulties."

The business plan stated that geo-data should be supplied by an increasing number of providers, via sophisticated Internet-based NCGI services. Geo-data providers were supposed to supply standardized metadata to the NCGI, stimulated by installing NCGI-certified software on their computers at their own risk and expense. This would be profitable for all parties: 'taking part in the NCGI is beneficial to them, because disseminating the metadata themselves would be more expensive' (NCGI 1998: p.24). The business plan presented the NCGI as 'up and running' and ready for the future. In an appendix to the plan, however, it was suggested that the NCGI might succeed, but that this analysis was only based on a 'non-evidenced gut feeling'. The appendix also explained that while the NCGI's website had met initial goals, it had not continued to meet expectations. The website and data were not findable, procedures to keep metadata upto-date were lacking, and that metadata needed to be appraised prior to publishing had not been anticipated. While the report itself was optimistic about the future, the appendix identified major flaws that were not mentioned in the main body of the text.

With a new office and a newly-appointed director, at the beginning of 1998, NCGI appeared to be ready for the future. Streamlining the internal information management of participating organizations was seen as essential, as they had been persuaded by the NCGI to follow a metadata course (Mom, 1998). However, in the spring of 1998, the NCGI was struck by severe technical problems, making the website inaccessible for about six months. At a user conference, at the time of which the NCGI's service provider had still failed to fix persistent problems, the NCGI explained the situation and launched new plans. A new distributed strategy should keep data and metadata within the source organization, and the NCGI would make it possible to both find and access these dispersed data via its website. Standardization was the 'name of the game'; the OpenGIS Standard would provide the distributed framework, which would be developed in pilot projects in 1999. The fact that only a very few data providers were willing to cooperate with the NCGI was underscored by the NCGI newsletter of February 2001, which can be interpreted as a desperate plea for help. It made a call for subscriptions to the NCGI, along with a quasipromotional list of the names and logos of the 15 organizations that were represented on the supervisory board.

According to quite a few interviewees, while the NCGI was in distress, supervisory board members were engaging in some serious power games. As a former board member reveals:

"The supervisory board of the NCGI was a society along the lines of 'the more things change, the more they stay the same". It was an all-male board of management 
executives of geo-data organizations, always keen to score off one another. They fully agreed that it was a good idea to exchange data, but did little to achieve that. They were serving their own interests, and that ultimately caused its downfall. They kept the NCGI alive but prevented it from blossoming. Every time it was about to die, they reanimated it, but in the end it never had a chance."

This impression of inertia on the supervisory board is reinforced by columns in the bimonthly RAVI newsletters, written by individuals holding management positions in geo-dataproducing organizations. From autumn 1997 until the end of 2000, quite a few managers gave their opinions. The diversity of expectations regarding NSDI in general and the NCGI in particular, is striking. Some merely saw the NCGI as a display window and as a means of advertising geo-data; others saw it as a means of realizing their own organizations' internal goals, and optimizing their own internal data organization. The executives of geo-data organizations only stressed the needs of their own individual organizations (Mom, 1995, 1998; Van Cann, 1995; Van der Valk, 1997). Nevertheless, the NCGI was always given a positive reception in professional journals.

\section{Moving Commercially Astray}

While NCGI continued to operate, it was far from financially sound. The supervisory board as a whole, however, kept the concept alive. At the end of 2001, it was time for change, as a supervisory board member explains:

"A newly-appointed director was taking measures and suggested selling the whole concept to a commercial company. And that is what happened. The clearinghouse concept, which was being implemented by government agencies in every other country, was going commercial. That was unique."

Members of the supervisory board, who were serving their own organizations' interests, now had to find a collective solution to the NCGI's budgeting problems, and they devised an exit strategy. Three consulting companies were invited to submit proposals for taking over the NCGI's website and webhosting activities. A consulting executive of the contract-winning company explains:

"As a company, we took the risk; the NCGI supervisory board kept on doing the organizational stuff. That the supervisory board should remain intact was one of our requirements. We arranged it all technically, and got going. One after another, ministries asked for our data and expertise. Projects in a multi-organization governmental setting usually failed, but single ministries generated a lot of work that turned out to be successful. However, customers wanted to do business with us, not with the NCGI. So, in the end, the NCGI became an obstacle for us, and we had to let it go. The NCGI evolved into a new form, with some casualties."

An individual from within the NCGI office observes:

"I saw it as an escape into the future. It was something like: it's dead, it's over, it's a failure, and now we try our chances at a new golden age. They called it a 'public- 
private partnership'. Governmental representation is always a problem in constructions like this. Here, different governmental organizations were actually unwilling to cooperate. The same patterns that we had seen before returned. It didn't solve anything."

In 2001, the NCGI foundation still held formal responsibility, but all of its operations were outsourced to a geo-software consultancy company (Mom, 2001). This consulting company, which was renowned for its innovative projects, was allowed to profit from these activities. As geo-professionals, a few management executives from within the consulting company had been closely involved with Idéfix. The plan was still to create a metadata catalogue and to disclose the 'underlying' data, and the consulting company's profile gave the NCGI greater credibility.

In October 2001, the NCGI presented itself as the 'Geo-Library of the Netherlands', willing to lend geo-information to 'governments and citizens with a subscription' (NCGI, 2001). It was announced that its search facilities would be improved, and that organizations would be able to promote their geo-data using 'thematic exhibitions'. The supervisory board was enlarged to include national government representatives, and new projects were launched to serve specific groups, such as those on land consolidation and spatial planning.

The bi-monthly newsletter started to resemble a consulting firm's brochure. It featured new contracts to showcase the NCGI's business activities, which were for the most part projects for single governmental bodies. These comprised data exchange, for which the NCGI only provided engineering and software development.

Meanwhile, the NCGI still claimed to be dedicated to data exchange. Its mission was formulated in the bi-monthly newsletter of March 2003:

"To manage and utilize a demand-driven neutral and public (standard-based) national geo-data infrastructure for the retrieval, use and exchange of geo-information. Through a dedicated NSDI-portal, governments and knowledge institutes, and at a later stage also citizens and the business community, can get access to geoinformation files from the Dutch government and geo-ICT businesses."

One new strategy was that of using portals. Portals were defined as thematic entry-points, whereby geo-information on certain topics, such as the environment or public safety, would be grouped together and easy to find. In the bi-monthly newsletter of June 2003, it was mentioned that four portals would be established as building blocks for an NSDI. As an organization, the NCGI was supposed to support the NSDI concept. People gradually started to see the NCGI as a concept, rather than as a tangible service. The perception was that the NSDI concept had evolved beyond the clearinghouse concept.

In April 2004, a separation was announced between the NCGI portal and the NCGI as a consultant-developer. In 2005, the newsletters described the NCGI as outdated, and suggested that its central organizational structure was badly suited to a decentralized concept. The final bimonthly newsletter of April 2006 remained optimistic, but by this time, the government ministry responsible had already announced that RAVI and the NCGI would soon be disbanded and replaced by a new coordinating agency.

Back in 2001, the Dutch government had founded a stimulation program called 'Space for Geo-information' (SGI), in order to promote innovation in the geo-data sector. While the NCGI was still in business, the Ruimte voor Geoinformatie (Space for Geoinformation, RGI) program 
encouraged organizations to make project proposals for SGI funding while promoting the NSDI concept. The SGI program solicited proposals and appraised these contributions on how they sustained the NSDI concept. One of the proposals that aimed to establish a system of geo-portals was awarded a grant, and implementation commenced in 2005. Geo-portals was seen as the successor of NCGI and while it was already considered as failed, it was encouraged by RGI that NCGI and Geoportals should cooperate.

\section{ANALYSIS AND CONCLUSION}

At first glance, the case would seem to demonstrate progress in the development of an NSDI. The clearinghouse concept appears to have been a step on the road towards more cooperation in the geo-information sector, prior to the establishment of an NSDI. Looking more closely, however, the ethnography presented above is a representation of the constant struggle to meet goals (Van Marrewijk, Clegg, Pitsis, and Veenswijk, 2008). On the one hand, efforts were made to structure technology and procedures, aimed at stimulating accessibility and predictability (Edwards, Jackson, Bowker, and Knobel, 2007). There was also a dynamic side, however, which was about conceptualizing the NCGI as a realm in which the latest technologies and concepts should always be used.

As long as the NCGI existed, its raison d'être was never a matter of discussion. It fostered the self-evident higher goal of geo-data exchange as the key to progress across the entire geoinformation sector. That conviction remained unquestioned, and therefore unchanged. The whole project seemed to propagate the unspoken message that the Netherlands would become a better place if its geo-information sector were able to exchange geo-data (cf. Veenswijk and Berendse, 2008). Now we will focus on this conceptualization in more detail, using the conceptualization of narrative setting, narrative spaces and narrative storyboards.

\section{Narrative Setting}

Regardless of its physical or legal whereabouts - whether on the RAVI premises, in a separate office location, or at a consulting company's offices - the NCGI was rewarded for its contribution to the sector. The location and ownership of the NCGI were not up for discussion, as the NCGI's image was one of being independent from other organizations, supported by the independent nature of being an Internet facility. The plan was that organizations should upload their metadata onto the NCGI website at their own expense, in an act of cooperation and unquestioning faith in the NCGI. When that plan failed, a new plan was launched. This time, the metadata sets would remain with the participating organization, and the NCGI would be reconceptualized as a system of distributed metadata sets. While individual organizations would remain responsible for their own storage costs, the system would be beneficial to all.

ICT was seen as a determining factor for both the genesis and the fate of the NCGI. As such, a claim was laid on the future: emerging environmental problems would eventually become vast problems that could only be tackled using future (web-based) technology. It created an opportunity to exchange data electronically and the new concepts needed to realize this. Using state-of-the-art technology was tempting, unquestioned, and almost inevitable for the existence of the NCGI. When Internet-based concepts were introduced, it appeared that every individual in the geo-data sector had a duty to apply them. Promising technological innovations were tested in pilot projects, but as soon as they were ready for implementation, new expectations were created by even newer promising technologies. The newly-tested technologies were never actually 
implemented, however, because newer goals were already in sight. Indeed, our findings suggest that no one seemed to mind when it turned out that a validated technique would not be used in everyday practice.

Within the NCGI project, the focus was on promising developments. Instead of applying today's technology, it was thought that the NCGI should only use tomorrow's technology (Van Lente, 1993). Riding the waves of change meant introducing promising techniques, which always needed to be tested before they could be applied.

\section{Narrative Space}

We can distinguish two narrative spaces that played a dominant role in the project: first, the space of the geo-data professionals; and second, the space of managers in geo-data-processing organizations. Within the NCGI, the initiative seems to have alternated between these two spaces.

The SAG initiative constituted a relatively formal exchange of ideas. It did not lead to any concrete actions, but functioned as a breeding ground for professionals to generate new ideas. When the Idéfix prototype was developed, it seemed logical to shift it to the inter-organizational management level, and institutionalize it within RAVI. After some time, the project was declared a failure, and the initiative returned to the professional level in the form of an outsourced engineering project. Soon it was discovered that this commercial contracting firm had other hopes and goals than those that had initially been defined for the management-instigated SGI program. The clearinghouse idea was initially adopted, but it was dropped at the geo-portal project stage, along with the professionals whose job it had been to develop it.

As a collectivity, the managers endorsed the NCGI's goals. As representatives of their respective organizations, however, they seem to have acted in the best interests of their own organizations, which in most cases contradicted those of the NCGI. It appears that as a collectivity, they were keen to promote the NCGI, but as individuals, they were reluctant to put this into practice.

The geo-data professionals, on the other hand, knew how technical problems concerning geodata exchange should be solved. They thought that it would be essential to apply new technology. Having produced the working Idéfix prototype, they felt that their task should be completed at a higher level, and that their 'baby' should mature and be institutionalized. The engineering contractor was seen as a professional actor that would 'set things right', thereby achieving this institutionalization. When the outsourced version of NCGI did not gain the success as it was intended to have, the space of geo-management took the initiative back and used the RGI program as a tool to make new plans for a system of Geoportals which had to be executed by geo-professionals again. In turn, the professionals saw the geo-portal project as confirmation that they were responsible for advancing the project, now that the managers had shown themselves to be incapable of doing so.

The NCGI shifted back and forth between the narrative spaces of the management and the geo-professionals (see figure 2). Every time such a change occurred, it was stated that the NCGI had failed, and that the space that had gained the initiative should deal with this. As soon as the initiative moved from one space to the other, the project was redefined. 
FIGURE 2

INITIATIVE-TAKING BY NARRATIVE SPACES

\section{Space of geo-management}

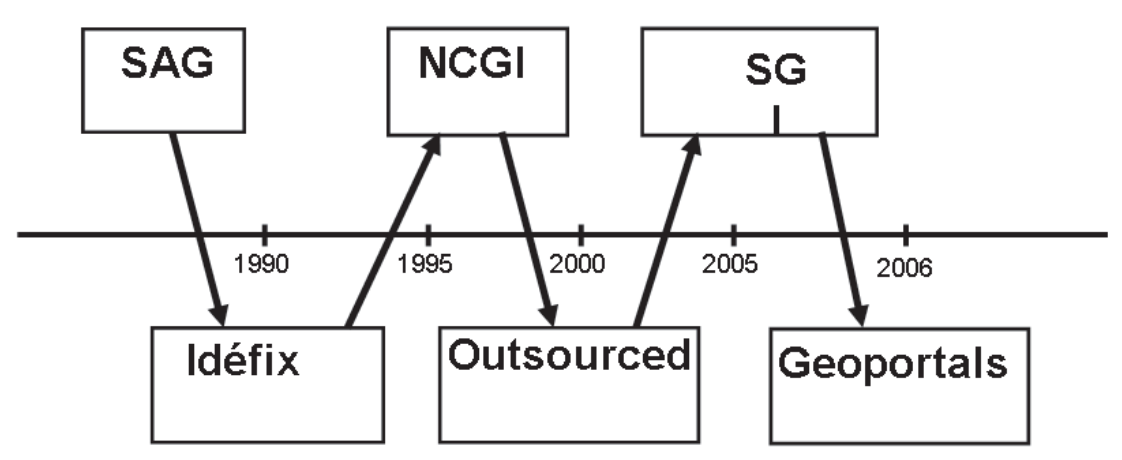

Space of geo-professionals

\section{Narrative Storyboard}

Storyboards are patterned, maybe even ritualized guides for action. Two storyboards can be identified guiding action, both of a cyclical nature, resembling vicious circles (Hampden-Turner, 1990; Masuch, 1985). One concerns the narrative setting, and the other concerns the narrative space.

Technology was the driving force for change, creating constant pressure to embed the latest developments. Every emerging concept had repercussions for the NCGI's approach. From the SAG to the geo-portal concept, when new technology called for new concepts, an obligation was felt to implement them in the NCGI. A technological innovation would be announced, would become available, and would be recognized as promising and tested. Once testing had taken place, it would be logical to expect that the technology would be applied. However, attention then shifted towards newer technology that enabled newer concepts, making the cycle complete. This fixation on new technology ultimately meant that the new developments were never used (see figure 3). In the data presented, two full cycles of this pattern can be identified.

In the drive to make the NCGI successful, the initiative alternated between the narrative spaces of the geo-professionals and the management, following its own storyboard. When the initiative was taken, a solution was presented and then implemented. When the results were assessed, the problem was redefined in terms of the other narrative space in order to enable a solution to be found (figure 4). In the redefinition phase, there was mostly mutual agreement between the narrative spaces as to how the problem needed to be redefined, so as to be acceptable for the narrative space responsible for solving it.

The two narrative spaces seemed to be unable to cooperate to make the NCGI successful. During its technological innovation cycles, the NCGI oscillated between managerially-driven 
and professionally-driven initiatives. The supervisory board had an 'upper echelon' image: it appeared to be out of touch with the 'shop floor' of geo-information professionals, but always had a keen eye for organizational interests. The geo-professionals, meanwhile, were convinced that geo-information had to be shared between the various organizations, and were prepared to do anything in order to realize this goal.

FIURE 3

THE STORYBOARD OF TECHOLOGICAL INNOVATION

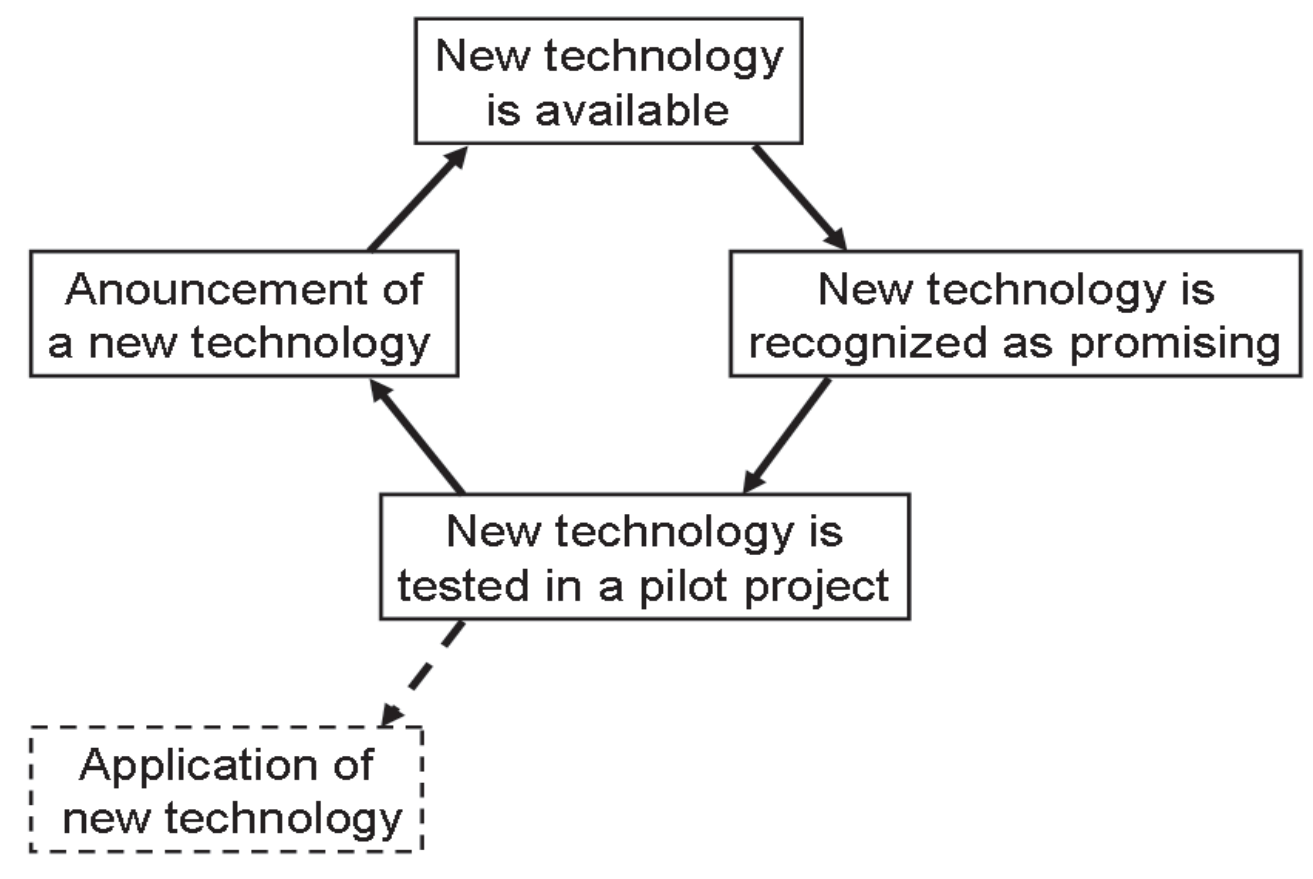

The cyclic storyboard outlined in figure 3 reveals an external and predominant environment of technological innovation, which functioned autonomously and could not be influenced by what happened within the NCGI. The initial notion that a promising technology would be able to solve today's problems in the future turned into strategy that was dominated by technology. This forced the NCGI to continuously move on, making it difficult to set the project's agenda. As a result of this implementation process, the clearinghouse was never realized.

The cycle presented in figure 4 reveals the degree of indecisiveness involved. Nobody felt responsible, because nobody had a way of dealing with the constant pressure to adopt new technology, which was inhibiting decision-making. Merely restructuring the organization was an insufficient response to this problem. A sector that had become dominated by technological innovations should have focused on the essence of the task in hand: building an infrastructure. 


\section{FIGURE 4 \\ THE STORYBOARD OF PROJECT REDEFINITION}

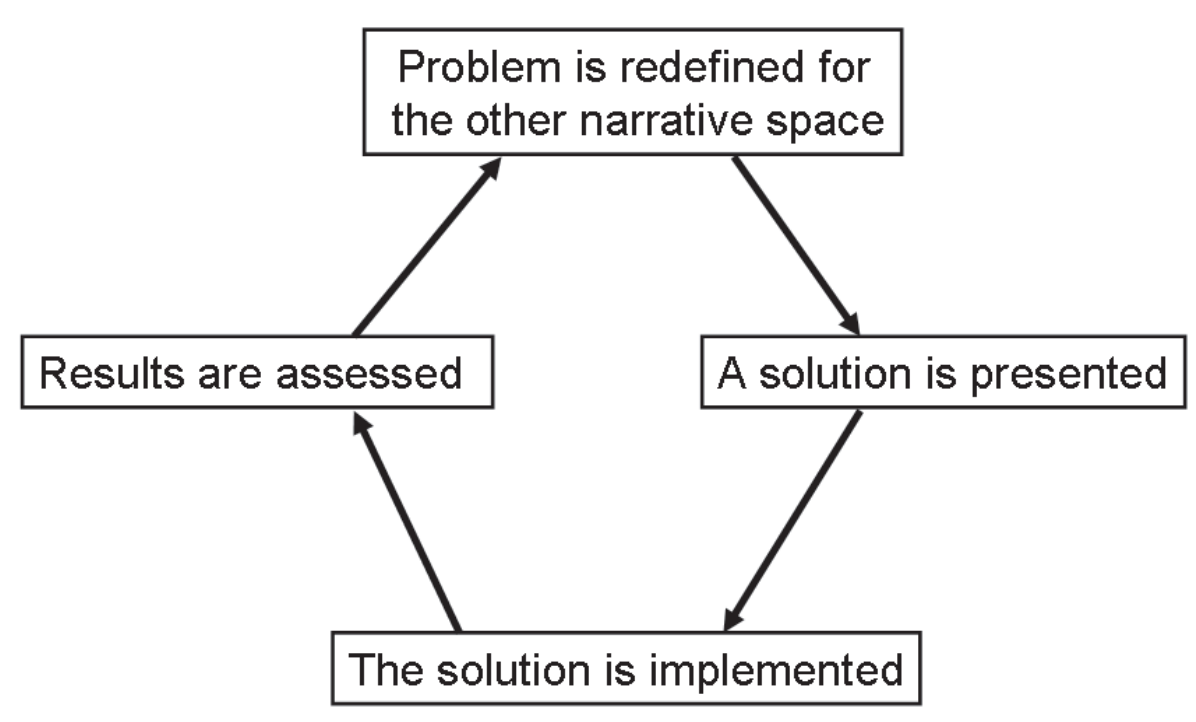

\section{Final Remarks}

By presenting this ethnography of an attempt to build a geoinformation infrastructure it becomes clear that the way technology has been used is the decisive element determining the fate of NCGI (Orlikowski, 2007).

The vicious circle should have been transformed into a virtuous circle. That is, the geoinformation sector should have shown that it was in control. In this way, technological innovations would only have been applied if they contributed to advancing the desired infrastructure (figure 5). This virtuous circle would force participants to think in terms of the infrastructure itself. In this case, technical innovations would not be forced onto the project, but would offer opportunities. Instead of becoming inevitable and inescapable, technological innovations would become infrastructural innovations that could be rejected if they proved to be unsuitable. Assessing infrastructural innovations would require taking an integral approach, which would avoid a storyboard such as the one outlined in figure 4 . The management and professional narrative spaces would need to work together on such an evaluation process, which would demand high levels of cooperation and initiative.

The results of this research are applicable to any high-tech infrastructural environment that is experiencing difficulties related to uncertainty and project definition (cf. Van Marrewijk, et al., 2008; Veenswijk, 2006; Veenswijk and Berendse, 2008). The research shows how technology can dominate the mental shaping and reshaping of infrastructures, invoking a storyboard that resembles a vicious circle and impeding the real development of an infrastructure.

In such cases, when professionals and managers are convinced that they are doing the right thing, both parties lack the knowledge needed to start building the real infrastructure, and pass the initiative between them without making any actual progress. Instead of allowing technology 
to dominate approaches to infrastructure, in such cases, a fundamental reorientation of what constitutes infrastructure is needed. Only then will it be possible to determine which existing and future technologies might be of use to achieve this.

FIGURE 5

A DESIRED STORYBOARD OF INFRASTRURAL INNOVATION

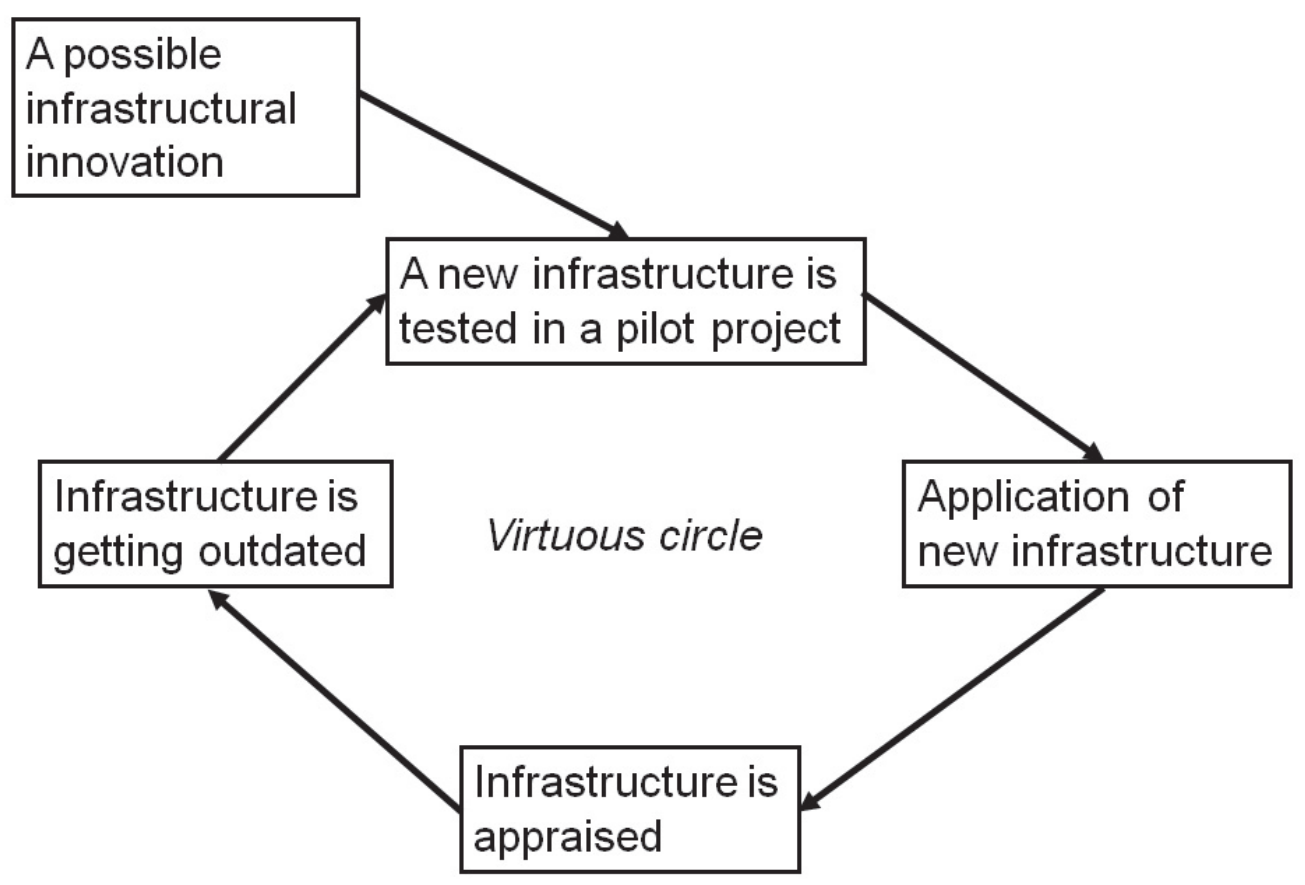

We conducted our ethnography in a hybrid environment composed of governmental- and private organizations, with a high technological turnover. As suggested above, these results may be applicable to similar dynamic environments. They shed light on the ever-dominating nature of technology, and how it can hamper the building of an electronic infrastructure. This interplay between dynamic technology and a rigid infrastructure remains uncontested research terrain, and further exploration of this field is needed.

\section{REFERENCES}

Barley, S. (1990). The Alignment of Technology and Structure through Roles and Networks. Administrative Science Quarterly, 35: 61-103.

Bartunek, J. (2004). The importance of contradictions in social interventions. Intervention Research, 1: 103-113.

Beech, N., and Huxham, C. (2003). Cycles of Identity Formation in Interorganizational Collaborations. International Studies of Management and Organization, 33(3): 28-52. 
Berger, P. L., and Luckmann, T. (1967). The social construction of reality, Harmondsworth: Penguin Books.

Bergson, H. (1946). The creative Mind, Westport CT: Greenwood Press.

Bijker, W. (1995). Of Bicycles, Bakelites, and Bulbs, Toward a Theory of Sociotechnical Change, Cambridge: The MIT Press.

Boje, D. (1995). Stories of the Storytelling Organization: a Postmodern Analysis of Disney as "Tamara-Land". Academy of Management Journal, 38(4): 997-1035.

Boje, D. (2001). Narrative Methods for Organizational and Communication Research, London: Sage Publications Ltd.

Boswinkel, J. (1991). Samenwerkingsverband Aardkundige Gegevensverstrekkende Instituten (SAG II). In J. Hooghart (Ed.), Geo-informatie in Nederland, Commissie voor Hydrologisch Onderzoek TNO, 49-56.

Bourdieu, P. (1998). Practical Reason, On the Theory of Action, Stanford CA: Stanford University Press.

Bourdieu, P., and Pels, D. (1989). Opstellen over smaak, habitus en het veldbegrip, Amsterdam: Van Gennep.

Bregt, A. (2000). The Dutch clearinghouse for geospatial information: cornerstone of the national geospatial data structure. In R. Groot and J. McLauglin (Eds.), Geospatial Data Infrastructure: concepts, cases and good practice, Oxford: Oxford University Press.

Bruner, J. (1991). The Narrative construction of Reality. Critical Inquiry, 18: 1-21.

Burke, K. (1969). A Grammar of Motives, Berkeley and Los Angeles: University of California Press.

Burrell, G. (1992). Back to the Future: Time and Organization. In M. Reed and M. Hughes (Eds.), Rethinking Organization, New Directions in Organization Theory and Analysis, London UK: Sage Publications Ltd, 165-183.

Chia, R. (2002). Essai: Time, Duration and Simultaneity: Rethinking and Change in Organizational Analysis. Organization Studies, 23(6), 863-868.

Clinton, W. (1994). Coordinating geographic data acquisistion and access to the National Spatial data Infrastructure. Executive Order 12096, Federal Register 59. Pp. 17671-4, Washington DC, USA.

Crompvoets, J. (2006). National Spatial Data Clearinghouses, Worldwide development and Impact, Wageningen: Wageningen Universiteit. 
Crompvoets, J., Rajabifard, A., Van Loenen, B., and Delgado Fernández, T. (Eds.). (2008). $\underline{A}$ Multi-View Framework to Assess SDIs. Melbourne, Au: Space for Geo-Information (RGI), Wageningen University and Centre for SDIs and Land Administration, Department of Geomatics, The University of Melbourne.

Czarniawska-Joerges, B. (1998). A Narrative Approach to Organization Studies (Vol. 43), Thousand Oaks CA: Sage Publications Inc.

Douglas, M. (1986). How Institutions Think, Syracuse: Syracuse University Press.

Duijnhoven, H. (2010). For Security Reasons; Narratives about Security Practices and Organizational Change in the Dutch and Spanish Railway Sector, Amsterdam: Vrije Universiteit Press.

Edwards, P., Jackson, S., Bowker, G., and Knobel, C. (2007). Understanding Infrastructure: Dynamics, Tensions, and Design. Report of a Workshop on "History and Theory of Infrastructure: Lessons for New Scientific Cyberinfrastructures.

Gabriel, Y. (2000). Storytelling in Organizations, Facts, Fictions, and Fantasies, Oxford UK: Oxford University Press.

Garfinkel, H. (1984). Studies in Ethnomethodology, Cambridge: Polity Press.

Georgiadou, Y., Puri, S. K., and Sahay, S. (2005). Towards a potential research agenda to guide the implementation of Spatial Data Infrastructures - A case study from India. International Journal of Geographical Information Science, 19(10): 1113-1130.

Georgiadou, Y., Rodriguez-Pabón, O., and Lance, K. (2006). Spatial Data Infrastructure (SDI) and E-governance: A Quest For Appropriate Evaluation Approaches. URISA Journal, 18(2): 4355.

Goffman, E. (1959). The Presentation of Self in Everyday Life, Garden City NY: Doubleday.

Goffman, E. (1974). Frame Analysis. New York: Harper and Row.

Golden-Biddle, K., and Locke, K. (1993). Appealing Work: An Investigation of How Ethnographic Texts Convince. Organization Science, 4(4): 595-616.

Gonos, G. (1977). "Situation" Versus "Frame": the "Interactionist"and the "Structuralist"Analyses of Everyday Life. American Sociological Review, 42: 854-867.

Grant, D., Hardy, C., Oswick, C., and Putnam, L. (Eds.). (2004). Organizational Discourse: Exploring the Field, Thousand Oaks CA: Sage Publications Inc. 
Grant, D., Keenoy, T., and Oswick, C. (Eds.). (1998). Discourse + Organization, London UK: Sage Publications Ltd.

Hampden-Turner, C. (1990). Corporate Culture, from vicious to virtuous circles, London: Hutchison Business Books Ltd.

NRC Handelsblad, (1995). Milieu verbetert, maar nog te veel CO2. September 19, 21.

Hanseth, O., Monteiro, E., and Hatling, M. (1996). Developing Information Infrastructure: The Tension Between Standardization and Flexibility. Science, Technology and Human Values, 21(4): 407-426.

Hatch, M., and Yanow, D. (2003). Organization Theory as an interpretive Science. In C. Knudsen and H. Tsoukas (Eds.), The Oxford Handbook of Organizational Theory, Oxford UK: Oxford University Press.

Hooghart, J. (1991). Geo-Informatie in Nederland, Paper presented at the Geoinformatie in Nederland: lezingendag, De Reehorst, Ede NL.

Koerten, H. (2008). Assessing the Organisational Aspects of SDI: Metaphors Matter. In J. Crompvoets, A. Rajabifard, B. Van Loenen and T. Delgado (Eds.), A Multi-View Framework to Assess SDIs, Melbourne: RGI, Wageningen University and University of Melbourne. Pp. 235254.

Latour, B., and Woolgar, S. (1986). Laboratory Life: The Construction of Scientific Facts, Princeton, Princeton University Press.

Lefebvre, H. (1991). The Production of Space, Oxford: Blackwell Publishers.

Lentjes, P., Bregt, A., Jellema, J., Kuipers, T., and Thewessen, T. (1993). Verder met SAG, Voorstel tot verbetering van gegevensuitwisseling tussen IGG-TNO, RGD, RIVM en SC-DLO, report nr. 267, Wageningen: DLO-Staring Centrum.

Lipsky, M. (1980). Street-Level Bureaucracy: Dilemmas of the Individual in Public Services, New York: Russell Sage Foundation.

Masser, I. (2005). GIS Worlds: Creating Spatial Data Infrastructures, Redlands CA: ESRI Press.

Masuch, M. (1985). Vicious circles in organizations. Administrative Science Quarterly, 30(1): 14-33.

Mom, P. (1995). MD, clearinghouse voor meta-informatie, VI Matrix, oktober.

Mom, P. (1998). Clearinghouse dwingt gemeenten informatiewarboel te reguleren. VI Matrix, februari. 
Mom, P. (2001). NCGI krijgt weer een nieuwe kans. VI Matrix, september.

NCGI (1998). Bedrijfsplan NCGI, Amersfoort: National Clearinghouse Geoinformatie.

NCGI (2001). NCGI nieuwsbrief: NCGI, de GeoBieb van Nederland, VI Matrix, oktober.

Nebert, D. (2004). The SDI Cookbook, http://www.gsdi.org/pubs/cookbook/.

Orlikowski, W. (2000). Using Technology and Constituting Structures: A Practice Lens for Studying Technology in Organizations. Organization Science, 11(4): 404-428.

Orlikowski, W. (2007). Sociomaterial Practices: Exploring Technology at Work. Organization Studies, 28(9): 1435-1448.

Polkinghorne, D. (1988). Narrative Knowing and the Human Sciences, New York: State University of New York Press.

Rajabifard, A., and Williamson, I. (2001). Spatial Data Infrastructures: Concept, SDI Hierarchy and Future Directions. Paper presented at the Geomatics '80, Tehran, Iran.

Ricoeur, P. (1973). The Model of the Text: Meaningful Action Considered as Text. New Literary Society, 5: 91-120.

RIVM (1993). Nationale Milieuverkenning 3 1993-2015, Alphen aan den Rijn: Rijksinstituut voor Volksgezondheid en Milieuhygiëne.

Schein, E. (1992). Organizational culture and leadership (2nd ed.), San Francisco: Jossey Bass.

Schein, E. (1996). Culture: The Missing Concept in Organization Studies. Administrative Science Quarterly, 41(2): 229-240.

Tesselaar, S., Sabelis, I., and Ligtvoet, B. (2008, july 23-25). Digesting stories - about the use of storytelling in a context of organizational change. Paper presented at the $\underline{\text { th International }}$ Conference on Organizational Discourse 2008, London UK.

Van Cann, H. (1995). Metadatamodellen lopen niet ver uiteen, structurering van 'gegevens over gegevens'. VI Matrix, september.

Van den Toorn, W., and De Man, E. (2000). Anticipating cultural factors of GDI. In R. Groot and J. McLauglin (Eds.), Geospatial Data Infrastructure: Concepts, cases and good practice, Oxford: Oxford University Press.

Van der Valk, M. (1997). Gebruik REGIS gaat niet tot op de bodem. VI Matrix, juni.

Van Lente, H. (1993). Promising Technology; The Dynamics of Expectations in Technological Developments, Delft: Eburon. 
Van Marrewijk, A., Clegg, S., Pitsis, T., and Veenswijk, M. (2008). Managing public-private megaprojects: Paradoxes, complexity, and project design. International Journal of Project Management, 26(6): 591-600.

Veenswijk, M. (2006). Surviving the Innovation Paradox: the Case of Megaproject X. The Public sector Innovation Journal, 11(2): 1-14.

Veenswijk, M., and Berendse, M. (2008). Constructing new working practises through project narratives. International Journal of Project Organisation and Management, 1(1): 65-85.

Verduijn, K. (2007). Tales of Entrepreneurship, Contributions to understanding entrepreneurial life, Amsterdam: PhD thesis Vrije Universiteit Amsterdam.

Watson, T. (2000). Ethnographic Fiction Science: Making Sense of managerial Work and Organizational Research Processes with Caroline and Terry. Organization, 7(3): 489-510.

Weick, K. E. (1995). Sensemaking in organizations, London: Sage Publications.

Wenger, E. (1998). Communities of Practice: Learning, Meaning and Identity, Cambridge UK: Cambridge University Press.

Yanow, D. (1995). Built Space as Story: The Policy Stories That Buildings Tell, Policy Studies Journal, 23(3): 407-422. 